\title{
The Tylawa Limestones - a regional marker horizon in the Lower Oligocene of the Paratethys: diagnostic characteristics from the type area
}

\author{
Agnieszka CIUREJ and Grzegorz HACZEWSKI
}

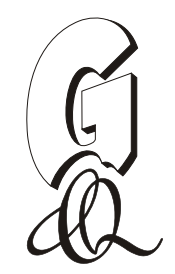

\begin{abstract}
Ciurej A. and Haczewski G. (2012) - The Tylawa Limestones - a regional marker horizon in the Lower Oligocene of the Paratethys: diagnostic characteristics from the type area. Geol. Quart., 56 (4): 833-844, doi: 10.7306/gq.1058

Three units of laminated coccolith limestone are used as regional chronohorizons in the Oligocene of the Outer Carpathians. Two of them - the Tylawa Limestones and the Jasło Limestone - display a similar type of lamination and their discrimination is in some cases problematic. We provide a detailed mesoscopic and microscopic lithological description of the Tylawa Limestones from the type locality at Tylawa and from Rudawka Rymanowska - the best exposure in the Polish Carpathians. The finely laminated limestone layers are up to $5.5 \mathrm{~cm}$ thick and are dispersed through a section more than $100 \mathrm{~m}$ thick. They are grouped in clusters. They differ from the younger Jasło Limestone in: (1) an absence of foraminifers, (2) a mass occurrence of Reticulofenestra ornata Müller, (3) the presence of voids after pennate diatoms, (4) dark laminae which are more pronounced than in the Jasło Limestone.
\end{abstract}

Agnieszka Ciurej, Institute of Geological Sciences, Polish Academy of Sciences, Senacka 1, 31-002 Kraków, Poland, e-mail: ndciurej@cyf-kr.edu.pl; Grzegorz Haczewski, Pedagogical University of Kraków, Podchorq ych 2, 30-084, Kraków, Poland, e-mail: grzehacz@up.krakow.pl (received: April 26,2012; accepted: May 20, 2012; first published online: November 15, 2012).

Key words: Tylawa Limestones, Outer Carpathians, coccolith limestone, chronohorizons, Oligocene.

\section{INTRODUCTION}

The Oligocene-Lower Miocene deposits of the Outer Carpathians are up to ca. $2 \mathrm{~km}$ thick and make up as much as a half of the entire Upper Jurassic through Lower Miocene succession of the Outer Carpathian fold-and-thrust belt. These synorogenic deposits were laid down in a basin whose communication with the open ocean became restricted in the Early Oligocene (Oszczypko, 2004). The Oligocene sequence consists of a variety of diachronous and laterally variable facies, from organic-rich black shales to coarse-grained gravity-driven mass-flow deposits. The sequence is poor in stratigraphically useful fossils and the presence of many endemic forms precludes precise biostratigraphic correlation with the coeval strata of the open ocean. This is why thin intercalations of pelagic coccolith limestone, concentrated in distinct isochronous horizons, have been extensively used as regional stratigraphic markers between various tectonic units and facies since the middle of the 20th century (see Jucha, 1957; Jucha and Kotlarczyk, 1958; Ślączka, 1959a, b; Koszarski and ytko, 1961; Jucha, 1969; Haczewski, 1984, 1989; Melinte, 2005; Kotlarczyk et al., 2006). Three of these horizons (Tylawa, Jasło and Zagórz horizons) have been recognized and mapped along nearly the whole length of the Carpathians, while a few others have been distinguished and named locally.

The limestones occur as millimetric to decimetric layers of coccolith limestone. In most sections they are split by clastic deposits that are usually much thicker than the limestone themselves. Correlation of laminae in the Jasło Limestone has shown that the clastic rocks represent event deposits, and the laminated limestone represents the bulk of the geological time during which the limestone unit was laid down (Haczewski, 1989). The laminae in the Jasło Limestone and Zagórz Limestone have been correlated across the major tectonic units and facies zones of the Outer Carpathians over distances up to $550 \mathrm{~km}$. Because of this the limestone horizons have been accepted as chronohorizons (sensu Racki and Narkiewicz, 2006). Some general mesoscopic characteristics help distinguish the limestones from the three major horizons. These characteristics include: type of lamination, abundance of fish remains, and presence of planktonic foraminifers. There are, however, many localities where identification of "Jasło-like" limestones is uncertain (e.g., Koráb and Kotlarczyk, 1977). This is because of: (1) heavy alteration of limestone by silicification, dolomitization, weathering, or tectonic fracturing, 
(2) substantial clastic admixture in the limestone that obscures the identity of laminae, (3) the limestone layers being too thin to study their lamination or faunal content, and (4) the presence of limestone layers not belonging to the previously defined horizons. The correlation of laminae in the Jasło and Zagórz limestones helps to overcome difficulty (1) in many cases, even when limestone fragments are found loose (Haczewski, 1984, 1989). Clastic admixture may result in uneven thickening and loss of definition of individual laminae, making them useless for correlation.

The Tylawa Limestones seem to be involved in most of the doubtful cases. Even if fine, regular lamination, abundance of fish and the lack of planktonic foraminifers are valid distinctive characteristics in classical good exposures of typical Tylawa Limestones, the lack of fish remains or foraminifers may reflect a fortuitously barren fragment of elsewhere fossiliferous rock at localities where only thin limestone layers, or small loose fragments of weathered limestone are present.

We provide here a detailed description of the structure of the Tylawa Limestones as seen mesoscopically as well as in optical and electron microscope images, with the aim of providing better criteria for their identification. We use material from the original locality at Tylawa and from the best exposure at Rudawka Rymanowska.

\section{CONCEPT OF THE TYLAWA LIMESTONES}

Thin layers of coccolith limestone in the Carpathian Flysch have been first noticed and reported by Uhlig (1882) near Jasło in a sandstone-and-shale turbidite sequence of the Krosno Beds. He soon found similar limestones around Bochnia within dark bituminous shales of Menilite type (Uhlig, 1884). He referred to them as "...those characteristic, fish-bearing calcareous shales from Jasło". This is the first use of the coccolith limestones in the Carpathian Oligocene as a regional marker between various facies.

The Uhlig's term "Kalkschiefer von Jasło", after translation to Polish and leaving out the "Kalk" part, has turned into "lupki jasielskie" (Jasło Shales) and was used for whitish-weathering platy limestones found at various localities. The finding that the limestones are extensive regional chronohorizons, among the facies units earlier considered as time-units, became a major break-through in the stratigraphy of the Outer Carpathians (Shakyn, 1958; Jucha and Kotlarczyk, 1958; Koszarski and ytko, 1959). Three separate horizons of "Jasło Shales" were traced over large areas. Jucha (1957) compiled information on the spatial and stratigraphic distribution of the limestones and noticed that strata resembling the "Jasło shales" occur also in the lower part of the Oligocene sequence in the inner part of the Silesian Unit (at Rudawka Rymanowska). Ślączka (1959a, b) found these limestones in the outer part of the Dukla Unit and described them as finely laminated limestones similar to the Jasło Shales. He also noticed that the Jasło Shales proper, situated higher in the stratigraphic sequence, are rich in globigerinids. In his monograph on the Dukla Unit, Ślączka (1971) confirmed the persistent stratigraphic position of the "Tylawa Shales" in the frontal part of the Dukla Nappe.
Studies on the abundant fish fauna in the Tylawa Limestones revealed that this, in the narrow stratigraphic interval encompassing the Tylawa Limestones, is clearly distinct from fish assemblages below and above (Jerzmańska and Kotlarczyk, 1968, 1981; Kotlarczyk et al., 2006).

Jucha (1969) introduced the name "lupki tylawskie" (Tylawa Shales) for the oldest horizon, after the classical locality in the Dukla Unit. Many mapping geologists (including A. Ślączka, pers. comm. to GH, 1998) suggested that the Tylawa Shales occur as several separate limestone horizons, stratigraphically close to one another. The fine, distinct lamination in the Tylawa Limestones has not been convincingly correlated over distances greater than ca. $20 \mathrm{~km}$ and the Tylawa Limestones seem to represent recurrent episodes of coccolith limestone deposition. That is why Haczewski (1989, pp. 442-443), presenting a typology and nomenclatural scheme for the three major chronohorizons of coccolith limestone, named the Tylawa Limestones in plural, in contrast with singular names for the Jasło Limestone and Zagórz Limestone. The Tylawa Limestones in their type area occur as millimetric to centimetric layers of coccolith limestone with a total thickness up to ca. $50 \mathrm{~cm}$ and are often grouped in clusters of closely spaced layers, all enclosed in a sequence of host sediments up to ca. $100 \mathrm{~m}$ thick.

Similar laminated limestones have been found at a similar stratigraphic position in other areas of the Silesian Unit, in the Subsilesian and Skole units, and referred to the Tylawa Limestones horizon (Koszarski and ytko, 1959; Jucha, 1969; Kotlarczyk, 1977, 1988; Kotlarczyk et al., 2006). The Tylawa Limestones occur in the lower part of the Menilite Beds in nannoplankton zone NP 23 of Martini (1971) (see Krhovský, 1981). The distinctive fish assemblage was used to define biozone IPM2 in the ichthyofaunal succession (Jerzmańska and Kotlarczyk, 1968, 1981; Kotlarczyk et al., 2006). Equivalents of the Tylawa Limestones have been recognized in the Alpine foreland basin in Austria (Müller and Blaschke, 1971; Schulz et al., 2005), in the Outer Carpathians from the Czech Republic, through Poland, Slovakia and Ukraine to Romania (Kotlarczyk, 1961; Koráb and Kotlarczyk, 1977; Haczewski, 1989; Krhovský et al., 1992; Melinte, 2005; MelinteDobrinescu and Brustur, 2008). Their recognition was based on the presence of laminated limestones in the lower part of the Oligocene succession, and was supported by data from fish, nannoplankton or both (see references above). Nannoplankton is usually preferred to fish as a means of rapid biostratigraphical diagnosis, but disintegration of the Tylawa Limestones for nannoplankton analysis usually results in samples described as barren of coccolithophores (see Ciurej, 2009).

Possible analogues of the Tylawa Limestones have been described from the successions in other parts of Paratethys Basin, east of the Carpathian area, mainly in the Caucasian region (Nagymarosy and Voronina, 1992; Muzylev et al., 1992). Published descriptions seem to suggest that the number and thickness of the laminated limestone layers increase to the south and south-east. The lithological descriptions provided in this paper may be used to evaluate the similarity of these deposits to the Tylawa Limestones. Besides the lithological similarities, the nature of the fish assemblage typical of the IPM2 zone of Kotlarczyk et al. (2006) should be 
considered a required diagnostic feature of any possible equivalents of the Tylawa Limestones.

\section{METHODS}

Sections with the Tylawa Limestones have been logged in the field at a scale of 1:10. Oriented (top-and-bottom) samples were taken from the complete thickness of the Tylawa Limestones and from the directly adjacent host strata of each limestone layer. The limestone samples were cut perpendicular to stratification and photographed in uniform lighting conditions. The photographs were digitally assembled into a continuous sequence of the laminated limestones from each locality, reproduced at the same scale.

Mesoscopic lithological description of the limestones was made millimetre by millimetre from the bottom to the top of each section on the cut and polished surfaces of the limestone layers. Microscopic examination was made on standard uncovered petrographic thin sections cut perpendicular to lamination and diagonally, at an angle of $50^{\circ}$ to lamination in order to better separate various levels within the laminae. The thin sections were studied with an Olympus SZX9 (transmitted light) polarizing microscope with a digital camera (Olympus $U$-TVO.5XC-2) steered by a computer using Analysis software and using a scanning electron microscope (SEM), using various modes of observation: charge contrast imaging (CCI) and back-scattered electrons (BSE). More technical details are given in Ciurej (2010). The SEM-CCI method allows study of anatomical details of calcareous nannofossils in strongly cemented samples that were regarded as barren of nannoplankton after standard separation treatment for calcareous nannofossils (Ciurej, 2009).

\section{DETAILS OF THE TYLAWA SECTION}

The Tylawa locality is generally accepted (Jucha, 1969; Ślaccka, 1973a, 1977) as the type locality of the Tylawa Limestones. The exposure lies in the eastern part of the Polish Carpathians, on the right bank of the Jasiołka River, ca. $1 \mathrm{~km}$ east of the international road E371 between Svidnik (Slovakia) and Dukla (Fig. 1). The lower part of the Menilite Beds of the Dukla Unit, exposed there, includes, from bottom to top: the Mszanka Sandstones, the Sub-Cergowa Marls (equivalent to the Dynów Marls) and the Cergowa Beds. The Cergowa Beds are bipartite in this section, with the lower division of the thickand thin-bedded Cergowa Sandstones overlain by the Cergowa Shales - marly, grey to brownish shales rhythmically alternat-

\section{Fig. 1. Location of study area}

A - simplified geological map of the Outer Carpathians with the location of the study area: C. F. - Carpathian Foredeep, I. C. - Inner Carpathians, P. B. - Pannonian Basin, PKB - Pieniny Klippen Belt, T. B. Transylvanian Basin, V. B. - Vienna Basin; B - simplified geological map of the Polish part of the Outer Carpathians (after Ksią kiewicz, 1972) with location of the sections studied; $\mathbf{C}$ - detailed location of Tylawa section; $\mathbf{D}$ - detailed location of the Rudawka Rymanowska section

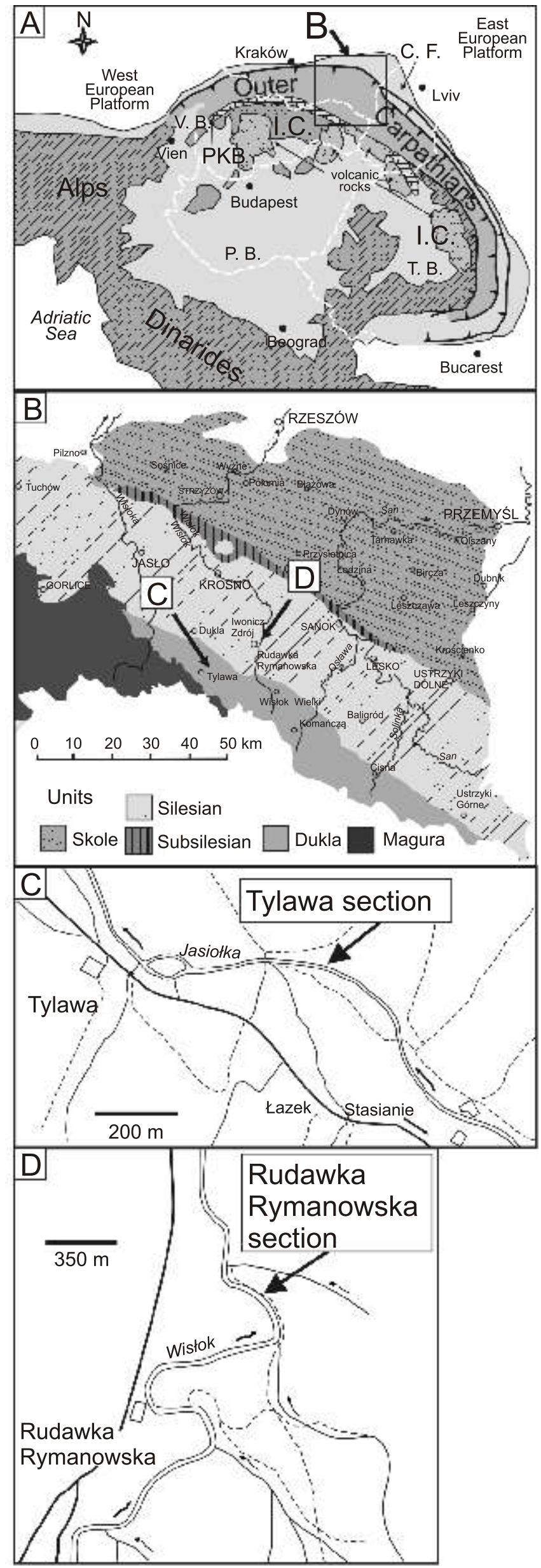


ing with thin- and medium-bedded grey micaceous calcareous sandstones. The facies of the Cergowa Shales laterally replaces the Menilite-type dark, organic-rich siliceous shales. The Tylawa Limestones are interlayered within the Cergowa Shales (Jucha, 1969; Ślączka, 1973a).

Detailed examination of the $115.3 \mathrm{~m}$ thick section has revealed a total of $18 \mathrm{~cm}$ of the Tylawa Limestones in 12 layers. The thin limestone layers are grouped in three clusters (Figs. 2 and 3). The two higher clusters, separated from one another by ca. $40 \mathrm{~m}$, are most likely those described by Jucha (1969) and Ślączka (1973a). Geographical coordinates (in WGS 84) of the exposure of the highest cluster were determined using a hand-held GPS receiver as: N49 $28^{\prime} 18.3^{\prime \prime}$ and E21 ${ }^{\circ} 43^{\prime} 21.3$ ". The third cluster of limestone layers, not described earlier, is exposed $65 \mathrm{~m}$ below the middle cluster at: N49 $28^{\prime} 17.1^{\prime \prime}$ and E21 ${ }^{\circ} 43^{\prime} 28.62$ '. All limestone layers display characteristic submillimetric to millimetric lamination consisting of alternations of light and dark laminae, though at some levels the mesoscopic visibility of laminae is obscured on weathered surfaces. The sequences of laminae differ slightly between and within the clusters in the thicknesses and proportions of the light and dark components.

The lowest cluster consists of two layers of laminated limestone (Figs. 2 and 3). The lower layer (6 mm thick) is poorly discernible against the encompassing black mudstone (TYL 2/07; Fig. 3). It consists of a bundle of thin laminae with a predominant dark component. The other layer lies $10 \mathrm{~cm}$ higher and displays distinct lamination (TYL 3/07; Fig. 3). Laminae of marly claystone are present among the bundles of limestone lamina couplets. This layer is underlain, with a sharp boundary, by non-laminated limestone and passes gradually upwards into pelletal marly claystone.

The middle cluster consists of two layers of laminated limestone within a succession dominated by shales and mudstones (Figs. 2 and 3). The lower layer consists of three bundles of limestone lamina couplets separated by grey marly mudstone. Lamination in the limestones within this layer is poorly visible (TYL 5A/07; Fig. 3). The higher layer also comprises three bundles of easily discernible limestone lamina couplets separated by grey marly mudstone (TYL 5/07; Fig. 3). This layer is underlain by grey claystone and overlain by dark-grey mudstone.

The highest cluster consists of eight thin layers of laminated limestone alternating with non-laminated limestones, mudstones, shales and sandstone (Figs. 2 and 3). Lamination in the two lowest limestone layers of this cluster (TYL 7/07 and TYL 8/07; Fig. 3) is poorly discernible mesoscopically and has a darker hue than the higher layers.

\section{DETAILS OF THE RUDAWKA RYMANOWSKA SECTION}

The section with the Tylawa Limestones at Rudawka Rymanowska is situated in the Iwonicz Zdrój anticline in the southern (inner) zone of the Silesian Unit in the eastern part of the Polish Outer Carpathians, ca. $25 \mathrm{~km}$ SE from Krosno, in the
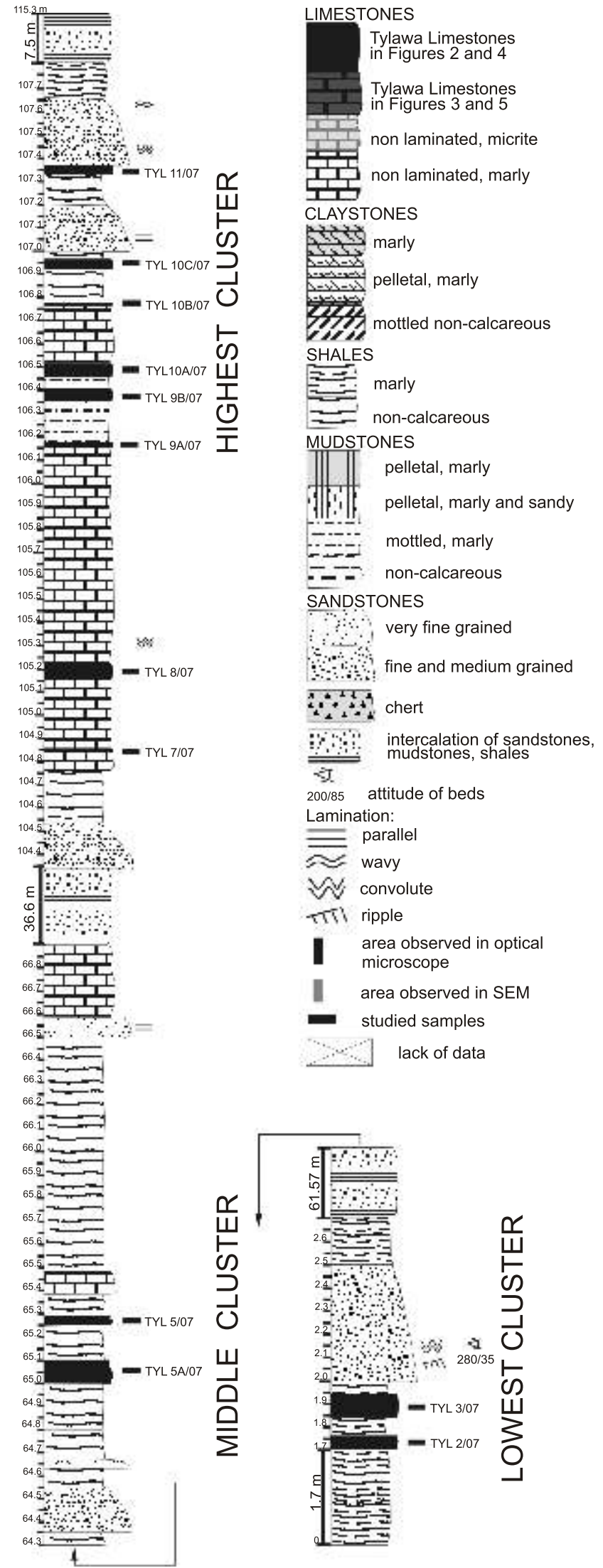

Fig. 2. Lithological column of the Tylawa Limestones at Tylawa as logged in 2007 with position of samples referred to in this paper 


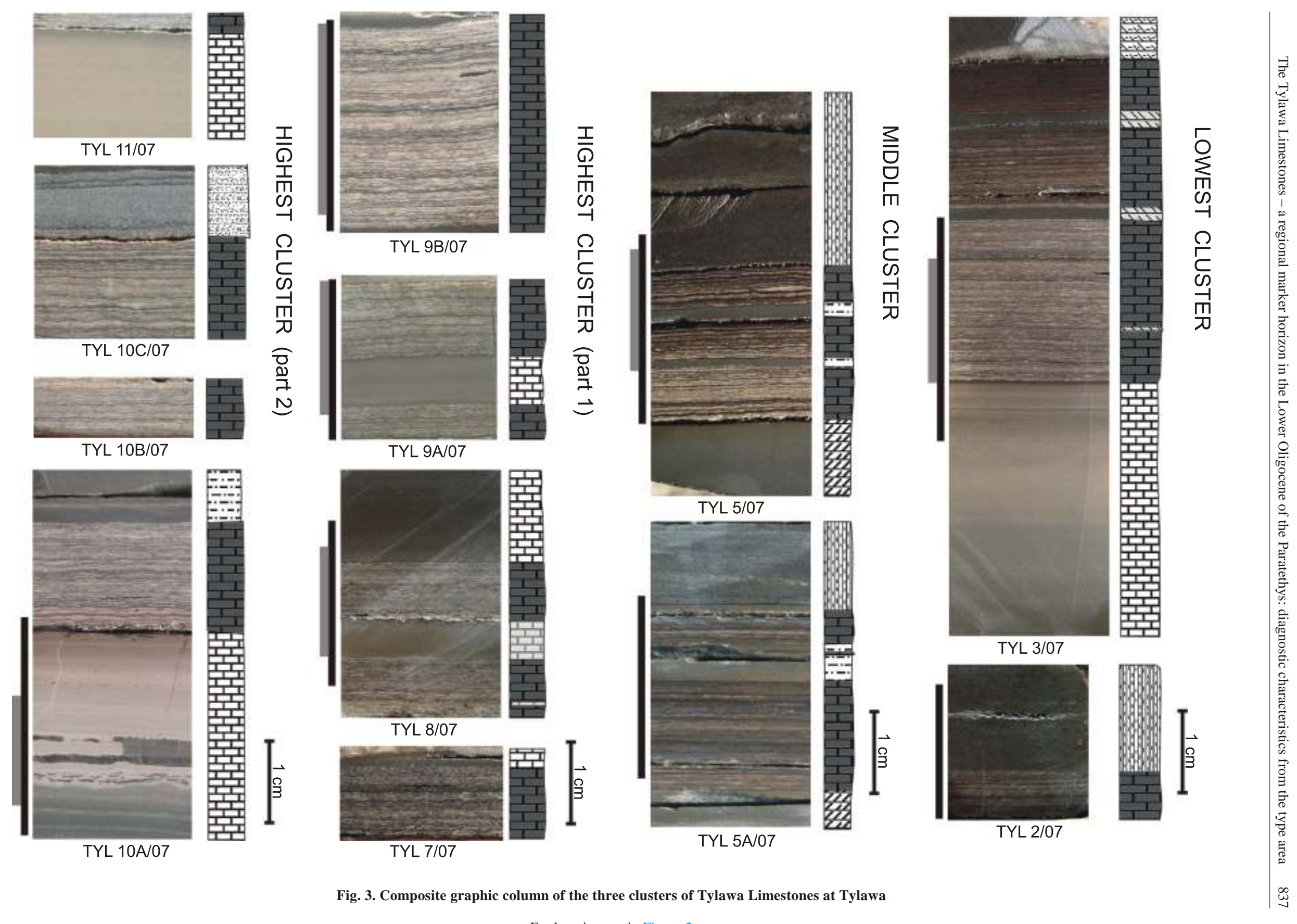

Explanations as in Figure 2 
Wisłok River bed (Fig. 1). The Tylawa Limestones are exposed there twice, displaced by a longitudinal fault, in exposures separated by ca. $750 \mathrm{~m}$, in a gently dipping sequence of the Menilite Beds. The number and quality of the exposures at Rudawka Rymanowska vary through time as a result of floods and human intervention (see Ślączka, 1973b; Haczewski, 1989; Ślączka and Kaminski, 1998; Bieńkowska, 2004; Ciurej, 2009). The limestones in both groups of exposures occur ca. $20 \mathrm{~m}$ above the top of the Cergowa Sandstones, in a succession of dark, non-calcareous organic-rich shale with cherts and limestones of Dynów Marl-type. Haczewski (1989) correlated laminae in the Tylawa Limestones on both sides of the fault and demonstrated that at least some layers of the dark shale are discontinuous laterally and that centimetric sequences of laminated limestones disappear over a distance of only $750 \mathrm{~m}$. Bieńkowska (2004) studied the fish fauna from three locations at Rudawka Rymanowska, on both sides of the fault.

The description below is based on the exposure on the northern side of the fault (arrow in Fig. 1D: N49 31'11.4", E21 $55^{\prime} 50.9$ '). A nearly complete section was surveyed, $18.6 \mathrm{~m}$ long (Fig. 4). The section includes 18 layers of the Tylawa Limestones with a total thickness of $38.7 \mathrm{~cm}$. Seven of these are thinner than $1 \mathrm{~cm}$ and the thickest is $5.5 \mathrm{~cm}$ thick. Most layers are clearly distinguishable mesoscopically among the host deposits; only the thinnest layers, consisting of few lamina couplets, are less distinct (Fig. 5). The characteristics of lamination are similar to those at Tylawa.

Thin intercalations within the laminated limestone layers are similar to those at Tylawa but more numerous. They include laminae of mudstone, claystone and micritic limestone. Some laminated limestone layers underlain by black mudstone have gradual transitions at their base, via the appearance of individual white laminae which increase upwards in thickness and density (RR 1/07, RR 9/06, RR 6A, RR 5/06; Fig. 5). Some limestone layers overlain by sandstones display, at their tops, structures attributable to erosion during sand deposition (RR 2/07 and RR 8/06; Fig. 5).

\section{HOST DEPOSITS OF THE TYLAWA LIMESTONES AT TYLAWA AND RUDAWKA RYMANOWSKA}

The layers of the Tylawa Limestones are intercalated with various deposits that change along the sections (Figs. 2-5). These include: thin- and medium-bedded grey, micaceous, calcareous sandstones, which may be very fine-grained and fine-grained, less frequently medium-grained. The sandstone layers display horizontal, wavy, and cross-lamination, rarely convoluted lamination, corresponding to $\mathrm{T}_{\mathrm{c}-\mathrm{d}}$ Bouma divisions. The shales in this section are grey, rarely dark brown, marly. Non-laminated limestones of Dynów Marl-type (limestone is the main lithology of the lithostratigraphic unit described as the Dynów Marls by Kotlarczyk and Leśniak, 1990) are present in this section as micritic and marly limestones, of yellow or brown hue and grey bands on freshly broken surfaces. Current-lamination and gradation, visible as gradual colour change, are locally present in the limestones. Centimetre-scale silicified zones are present within the limestones at some levels in the form of lenses, nodes, diagonal veins and meshworks.

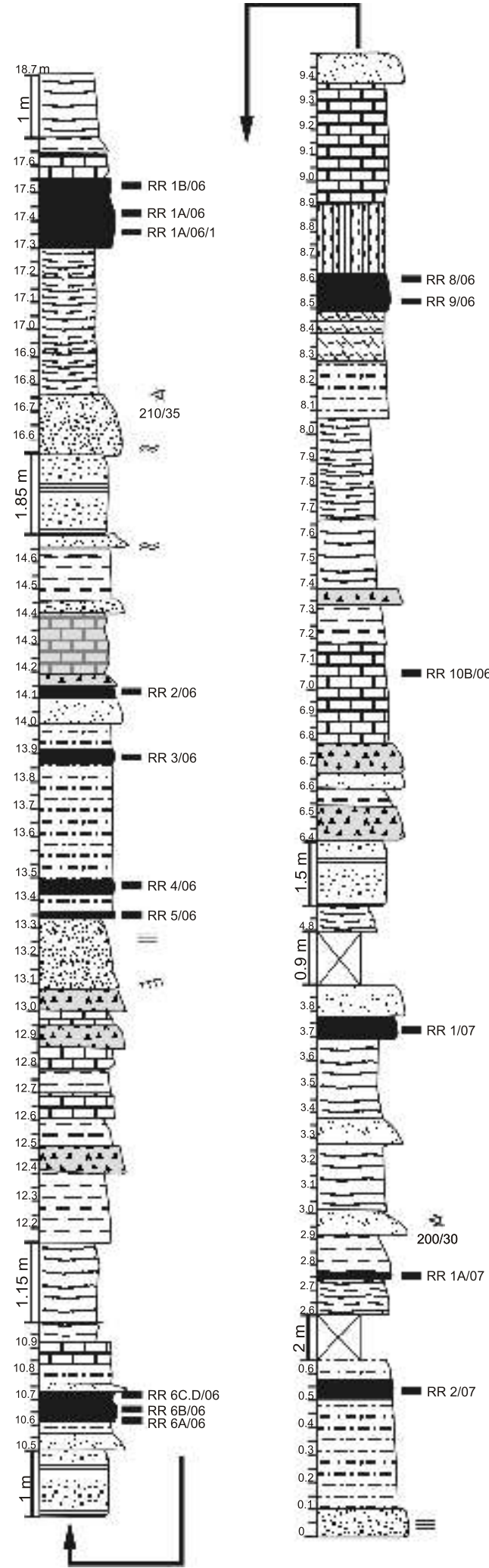

Fig. 4. Lithological column of the Tylawa Limestones at Rudawka Rymanowska as logged in 2006 and 2007 with position of samples referred to in this paper

Explanations as in Figure 2 


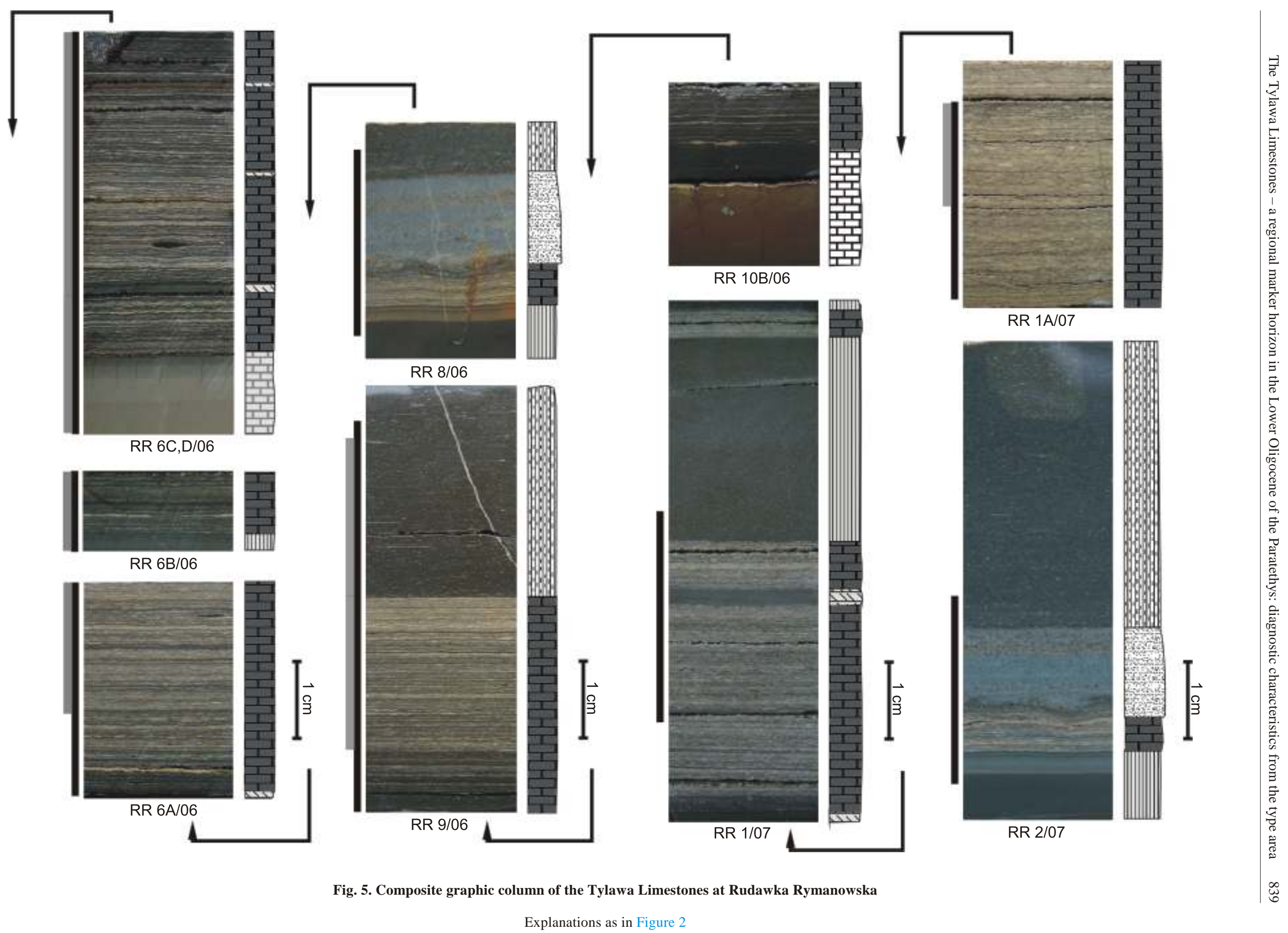




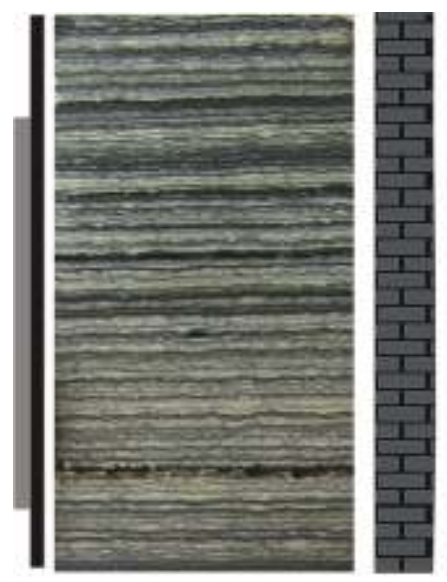

RR 1B/06
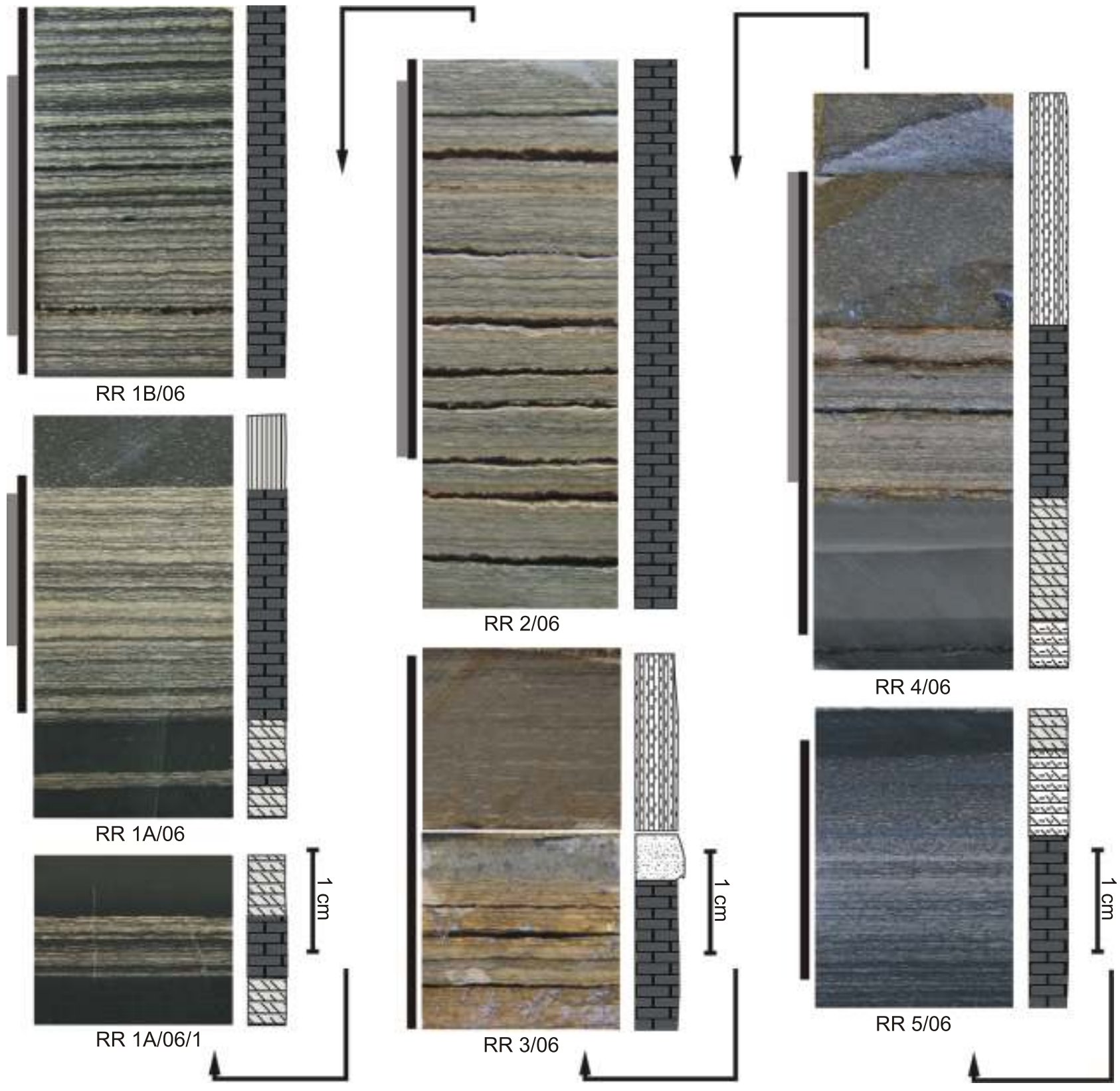

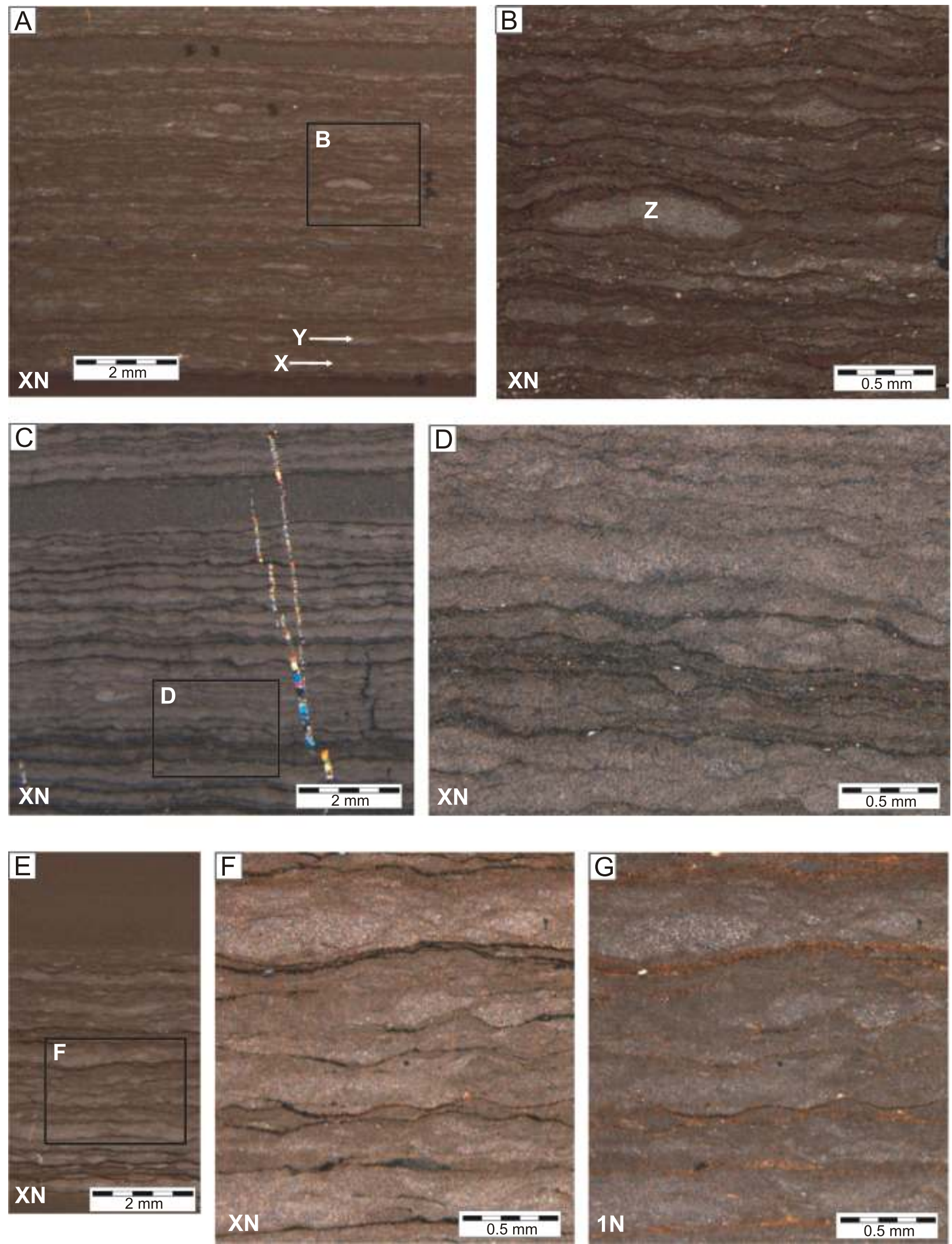

Fig. 6. Thin sections of Tylawa Limestones from Tylawa

A, B - lower cluster (TYL 3/07); C, D - middle cluster (TYL 5/07); E, F, G - upper cluster (TYL 9A/07). Thick light laminae composed of coccolithophores (Fig. 7) are separated by thinner dark laminae, composed of detrital material (Fig. 8). All laminae are laterally continuous and have undulose boundaries. Distinct pelletal structures composed of coccolithophores are present in all light laminae. Their size, shapes, and distribution vary within individual laminae. Optical microscope: $1 \mathrm{~N}$ - plane polarized lightl, $\mathrm{XN}$ - crossed polars. X,Y, Z - position of light laminae and pellets enlarged in Figure 7 
On weathered surfaces the limestones are characteristically whitish to light-grey. The Dynów Marl-type limestone layers are from a few millimetres to a few tens of centimetres thick. Their boundaries with the encompassing deposits are sharp and distinct. The section studied includes also black and dark-brown cherts up to $20 \mathrm{~cm}$ thick and grey, black, less frequently green and grey-green marly and carbonate-free claystones and mudstones.

\section{MICROSCOPIC CHARACTERISTICS OF THE TYLAWA LIMESTONES}

When examined in thin section using an optical microscope, the Tylawa Limestones display very thin lamination composed of alternating light and dark laminae (Fig. 6). The light laminae, 20-300 $\mu \mathrm{m}$, exceptionally up to $600 \mu \mathrm{m}$, in thickness, have a structure described as micronodular lami-


Fig. 7. SEM-CCI images from thin sections, showing coccolithophore remains in light laminae in various states of preservation

A - massive accumulation of well-preserved coccospheres; $\mathbf{B}, \mathbf{C}, \mathbf{D}$ - various fragmented coccospheres and coccoliths. Note the minimal alteration by dissolution, overgrowth or compaction; signs of advanced diagenesis are seen only locally (lower right of D); $\mathbf{E}-$ association of various fragments of coccoliths and intact coccospheres (upper right part) within laminae. Alteration by dissolution, overgrowth or compaction is seen only locally (lower and middle part). Arrows in C and E mark boundaries of pellets. Positions of A, B, C shown in Figure 6A: X-C, Y-B, Z-A. D-sample TYL 8/07; E-sample TYL 9B/07 



Fig. 8. SEM-BSE images from thin sections, showing components within dark laminae

A - association of various amounts of detrital material (clay minerals, quartz, feldspars), pyrite, carbonate grains and organic matter; note the difference in size of detrital material; B - predominance of pyrite and finest detrital material (clay minerals, quartz, feldspars); Tm - detrital material (clay minerals, quartz, feldspars); P - pyrite; W - carbonate grains; outlines - organic matter. A - sample TYL 8/07; B - sample TYL 9B/07

nated (Haczewski, 1989), with ovoidal pellets, averaging $50 \mathrm{x}$ $150 \mu \mathrm{m}$ in size, arranged in horizontal laminae. The pellets are interpreted as faecal pellets of zooplankton (see Haczewski, 1989; Ciurej, 2009). The laminae differ in pellet size, shape and packing. These differences result in fluctuating thicknesses of the laminae and in the nature of their boundaries - more or less undulose, and more or less sharp.

Analysis by SEM, in CCI mode, revealed that coccolithophore skeletons are the main component of the light laminae (Fig. 7). Nearly all the coccolithophore skeletal material is packed in pellets. The calcareous nannofossils are represented by a low-diversity assemblage dominated by Reticulofenestra ornata Müller (see Ciurej, 2009). Preservation of the coccolithophore material is very good in most of the laminae studied. There is little indication of dissolution or secondary overgrowth and of mechanical fragmentation by compaction. A strikingly large part of the cocccolithophore material is preserved as intact coccospheres (Fig. 7A). The scarce matrix in the light laminae consists of clay minerals, carbonate grains, pyrite and organic matter and it is present within pellets as well as between them.

The typical dark laminae are thinner than the light ones, between 3 and $30 \mu \mathrm{m}$ in most cases, exceptionally up to $100 \mu \mathrm{m}$ (Fig. 6). About half of the dark laminae are thinner than $10 \mu \mathrm{m}$. Analysis of the laminae by SEM using BSE mode reveals that they are composed of clay minerals (most likely kaolinite and illite), quartz, feldspars, carbonate minerals (calcite, ankerite, siderite, and dolomite), pyrite, phosphorus debris (fish debris) and organic matter (Fig. 8). Ghosts of pennate diatoms are present as deformed voids and indistinct imprints (see Ciurej, 2009).

\section{CONCLUSIONS}

Identification of the Tylawa Limestones on the grounds of their mesoscopic lithology may be problematic because of variation in contrast and colour of laminae. Microscopic examination by optical microscope and SEM provides more lithological and micropaleontological diagnostic criteria that may be summarized as follows:

- absence of foraminifers,

- mass occurrences of Reticulofenestra ornata Müller,

- voids after pennate diatoms,

- dark laminae that are more distinct and individual in nature than in the Jasło Limestone.

Acknowledgements. This study was partly financed by the Ministry of Science and Higher Education (MNiSW) grant 18.18.140.652 to GH and by the National Science Centre (NCN) grant 2011/01/D/ST10/04617 to AC. The microscopic study was done by $\mathrm{AC}$ within a $\mathrm{PhD}$ project supervised by $\mathrm{GH}$. The general description and interpretation has been written by both authors. We appreciate helpful reviews by M. MelinteDobrinescu and H. M. Schulz and the revision of the English text by J. Zalasiewicz.. 


\section{REFERENCES}

BIEŃKOWSKA M. (2004) - Taphonomy of ichthyofauna from an Oligocene sequence (Tylawa Limestones horizon) of the Outer Carpathians, Poland. Geol. Quart., 48 (2): 181-192

CIUREJ A. (2009) - Procesy i warunki sedymentacji wapieni tylawskich w oligocenie Karpat zewnętrznych (ze szczególnym uwzględnieniem polskiej części Karpat). Unpubl. Ph.D. thesis, Akademia Górniczo-Hutnicza, Kraków.

CIUREJ A. (2010) - Procedures for obtaining optimal SEM images of coccolithophore debris in coccolith limestones. Acta Palaeont. Pol., 55: 169-171.

HACZEWSKI G. (1984) - Correlation of laminae in chronohorizons of Jasło limestone and Zagórz limestone (in Polish with English summary). Kwart. Geol., 28 (4): 675-688.

HACZEWSKI G. (1989) - Coccolith limestone horizons in the Menilite-Krosno Series (Oligocene, Carpathians): identification, correlation, and origin (in Polish with English summary). Ann. Soc. Geol. Pol., 59: 435-523.

JERZMAŃSKA A. and KOTLARCZYK J. (1968) - Ichthyofaunal assemblages in the Menilite Beds of the Carpathians as indicators of sedimentary environment (in Polish with English summary). Rocznik Pol. Tow. Geol., 38: 39-66.

JERZMAŃSKA A. and KOTLARCZYK J. (1981) - Fish fauna evolutionary changes as the basis of the stratigraphy of the Menilite Beds and Krosno Beds (in Polish with English summary). Zemní Plyn a Nafta, 26: $63-74$

JUCHA S. (1957) - Jasło shales in Flysch Carpathians (in Polish). Prz. Geol., 5: (11) 521-525.

JUCHA S. (1969) - Les schistes de Jasło, leur importance pour la stratigraphie et la sédimentologie de la série ménilitique et des couches de Krosno (Carpathes flyscheuses) (in Polish with French summary). Pr. Geol. PAN Krak., 52: 1-128.

JUCHA S. and KOTLARCZYK J. (1958) - Trial of new stratigraphic division of menilite series and Krosno beds (in Polish). Nafta, 14 (8): 205-207.

KORÁB T. and KOTLARCZYK J. (1977) - Upper Palaeogene of the Dukla Unit in the Slovak Carpathians and an attempt for parallelizing it with the Polish Palaeogene (in Polish with English summary). Ann. Soc. Geol. Pol., 47: 95-114.

KOSZARSKI L. and YTKO K. (1959) - Remarks on Development and Sratigraphical of the Jasło Shales in the Menilitc and Krosno Series of the Middle Carpathians (in Polish with English summary). Kwart. Geol., 3 (4): 996-1015.

KOSZARSKI L. and YTKO K. (1961) - Jasło shales within the Menilite-Krosno Series in the Middle Carpathians (in Polish with English summary). Biul. Inst. Geol., 166: 87-232.

KOTLARCZYK J. (1961) - Possibilitès d'une corrèlation plus exacte du palèogène des Karpates Roumaines. Bull. Acad. Pol. Sc., Sér. Sc. Geol. Géogr., 9: 91-97.

KOTLARCZYK J. (1977) - Łupki tylawskie w jednostce skolskiej Karpat polskich. Spraw. Pos. Komisji Nauk. PAN Krak., 20: 182-183.

KOTLARCZYK J. (1988) - Geology of the Przemyśl Carpathians "a sketch to the portrait" (in Polish with English summary). Prz. Geol., 36 (6): 325-333.

KOTLARCZYK J. and LEŚNIAK T. (1990) - Lower part of the Menilite Formation and related Futoma Diatomite Member in the Skole Unit of the Polish Carpathians (in Polish with English summary). Wyd. Akademii Górniczo-Hutniczej, Kraków.

KOTLARCZYK J., JERZMAŃSKA A., ŚWIDNICKA E. and WISZNIOWSKA T. (2006) - A framework of ichthyofaunal ecostratigraphy of the Oligocene-Early Miocene strata of the Polish Outer Carpathian basin. Ann. Soc. Geol. Pol., 76: 1-111.

KRHOVSKÝ J. (1981) - Mikrobiostratigrafické korelace vnějších jednotek flyšového pasma a vliv eustatických změn na jejich paleogeografický vývoj. Zemní Plyn a Nafta, 26: 665-688.

KRHOVSKÝ J., ADAMOVÁ J., HLADÍKOVÁ J. and MASLOWSKÁ H. (1992) - Paleoenvironmental changes across the Eocene/Oligocene boundary in the Ždanice and Pouzdrany Units (Western Carpathians, Czechoslovakia): the long-term trend and orbitally forced changes in calcareous nannofossil assemblages. In: Nannoplankton Research (eds. B. Hamršmíd and J.R. Young). Proc. of the Fourth INA Conference, Prague 1991. Knihovnička Zemnyho Plynu a Nafty, 14b (2): $105-155$.

KSIĄ KIEWICZ M. (1972) - Budowa Geologiczna Polski, IV. Karpaty, cz. 3. Tektonika: 145-203. Wyd. Geol., Warszawa.

MARTINI E. (1971) - Standard Tertiary and Quaternary calcareous nannoplankton zonation. In: Proceedings of the II Planktonic Conference, Roma, 1970 (ed. A. Farinacci). Edizioni Tecnoscienza, Roma, 2: 739-785.

MELINTE M. (2005) - Oligocene paleoenvironmental changes in the Romanian Carpathians, revealed by calcareous nannofossils. Studia Geol. Pol., 124: 341-352.

MELINTE-DOBRINESCU M. and BRUSTUR T. (2008) - Oligocene-Lower Miocene events in Romania. Acta Palaeont. Romaniae, 6 : 203-215.

MUZYLEV N.G., TABASHNIKOVA I.P. and VORONINA A.A. (1992) Ranneoligotsenovyi epizod opresnenia w basseynakh Paratetisa. Seria Geologicheskaya, N5: 39-51.

MÜLLER G. and BLASCHKE R. (1971) - Coccoliths: important rock-forming elements in bituminous shales of central Europe. Sedimentology, 17: 119-124.

NAGYMAROSY A. and VORONINA A. (1992) - Calcareous nannoplankton from the Lower Maikopian Beds (Early Oligocene, Union of Independent States). Knihovnička Zemnyho Plynu a Nafty, 14b (2): 189-221.

OSZCZYPKO N. (2004) - The structural position and tectonosedimentary evolution of the Polish Outer Carpathians. Prz. Geol., 52 (8/2): 780-791.

RACKI G. and NARKIEWICZ M. (2006) - Polskie zasady stratygrafii. Państw. Inst. Geol.

SCHULZ H.M., BECHTEL A. and SACHSENHOFER R.F. (2005) - The birth of the Paratethys during the Early Oligocene: from Tethys to an ancient Black Sea analogue? Global Planet. Change, 49: 163-176.

SHAKYN V.O. (1958) - Goryzont smugastykh vapnyakiv i yiogo znachennya dlya zistavlennyya olygotsenovykh vikladiv. Dop. Akad. Nauk URSR: 414-416.

ŚLĄCZKA A. (1959a) - Stratigraphy of the Dukla folds in the Komańcza Wisłok Wielki region (Carpathians) (in Polish with English summary). Kwart. Geol., 3 (3): 583-604.

ŚLĄCZKA A. (1959b) - New data on development of Krosno beds in Bobova syncline and south of Tarnawa - Wielopole (in Polish with English summary). Kwart. Geol., 3 (3): 605-619.

ŚLĄCZKA A. (1971) - The geology of the Dukla unit (in Polish with English summary). Pr. Inst. Geol., 63: 1-98.

ŚLĄCZKA A. (1973a) - Wycieczka 5: Dukla-Lipowica-Trzciana -Jaśliska-Tylawa. In: Przewodnik geologiczny po wschodnich Karpatach fliszowych (eds. S. Gucik et al.): 111-120. Wyd. Geol., Warszawa.

ŚLĄCZKA A. (1973b) - Wycieczka 6: Besko-Sieniawa-Rudawka Rymanowska. In: Przewodnik Geologiczny po wschodnich Karpatach fliszowych (eds. S. Gucik et al.): 121-134. Wyd. Geol., Warszawa.

ŚLĄCZKA A. (1977) - Problem I-A: Rozwój facjalny i problemy paleogeograficzne młodszego paleogenu jednostki dukielskiej. In: Przewodnik XLIX Zjazdu Polskiego Towarzystwa Geologicznego, Krosno, 22-25 września 1977 (ed. A. Ślączka): 73-87. Wyd. Geol., Warszawa.

ŚLĄCZKA A. and KAMINSKI M.A. (1998) - Excursion guidebook, Polish Flysch Carpathians. Grzybowski Found. Spec. Publ., 6: 1-171.

UHLIG V. (1882) - Reisebericht aus Westgalizien: Funde cretazischer und alttertiärer Versteinerungen. Verh. Geol. Reichsanst., (15-16): 306-307.

UHLIG V. (1884) - IV. Reisebericht aus Westgalizien. Über die Gegend von Bochnia und Czchów. Verh. Geol. Reichsanst., (16): 336-339. 